\title{
An Antioxidant Combination Improves Histopathological Alterations and Biochemical Parameters in D-Galactosamine- Induced Hepatotoxicity in Rats
}

\author{
Tunc Catal' ${ }^{\text {, Sevim Tunali }}{ }^{2 *}$, Sehnaz Bolkent ${ }^{3}$, Refiye Yanardag ${ }^{2}$ \\ Uskudar University, Faculty of Engineering and Natural Sciences, Department of Molecular Biology, Istanbul, Turkey \\ ${ }^{2}$ Istanbul University, Faculty of Engineering, Department of Chemistry, Istanbul, Turkey \\ ${ }^{3}$ Istanbul University, Faculty of Science, Department of Biology, Istanbul, Turkey
}

Please cite this article as: Catal T, Tunali S, Bolkent S, Yanardag R. An Antioxidant Combination Improves Histopathological Alterations and Biochemical Parameters in D-Galactosamine-Induced Hepatotoxicity in Rats. Eur J Biol 2017; 76(1): 14-9.

\begin{abstract}
The protective effects of a combination of antioxidants on histopathological changes and biochemical parameters were examined in D-galactosamine (D-GaIN)-induced hepatotoxicity in rats. Physiological saline solution was injected intraperitoneally into the control group, while D-GaIN $\left(500 \mathrm{mg} \mathrm{kg}^{-1}\right)$ was administered intraperitoneally into the experimental animals. The combination of $100 \mathrm{mg} / \mathrm{kg} /$ day ascorbic acid, $100 \mathrm{mg} / \mathrm{kg} /$ day alpha tocopherol, $15 \mathrm{mg} / \mathrm{kg} /$ day beta carotene, and $0.2 \mathrm{mg} / \mathrm{kg} /$ day sodium selenate was administered orally to intact control rats for 3 days. The same antioxidant combination was given to the D-GalN group. Liver and blood samples were used for histopathological and biochemical assays. Liver tissues were significantly damaged by D-GaIN administration based on the histopathological findings. Serum aspartate and alanine transaminase, gamma glutamyl transpeptidase, alkaline phosphatase, lactate dehydrogenase, sialic acid, and uric acid levels increased. Serum and liver glutathione levels decreased, and serum superoxide dismutase, glutathione peroxidase, and glutathione-S-transferase, catalase activities as well as lipid peroxidation values increased in the D-GalN group. In contrast, administration of the antioxidants reversed the histopathological and biochemical changes in the liver of animals administered D-GaIN. In conclusion, the administration of a combination of antioxidants suppressed histopathological changes and biochemical parameters in rats given D-GalN.
\end{abstract}

Keywords: Vitamin C, $\beta$-carotene, D-galactosamine, sodium selenate, vitamin E, liver damage

\section{INTRODUCTION}

Acute liver failure is the rapid development of hepatocellular dysfunction triggering a cascade of events that damages multiple organs. Various agents, such as acetaminophen, hepa wash, and concanavalin cause acute liver damage in animal models, and D-galactosamine (D-GaIN) is a well-established model in experimental animals, such as rats (1-6). Several compounds, such as dobutamine, scoparone, polydatin, proline, and triterpenoids are protective against liver failure (7-11) and the possible role of various antioxidants is under study.

Selenium is a trace element with a significant role in sustaining health. It is a cofactor of glutathione peroxidase (GPx) and protects cells against reactive oxygen species (ROS) $(12,13)$. Vitamin $C$ has endogenous antioxidant features, and it has synergistic effects in combination with vitamin $E$ that protect low-density lipoprotein from oxidative stress induced by peroxyl radicals $(14,15)$. Vitamin $E$ serves as a free radical scavenger that protects fatty acids in bio-membranes and lipoproteins (16). Similarly, $\beta$-carotene is a major source of retinoids (vitamin A) in the human diet (17). The protective roles of selenium, vitamin $C$, and vitamin $E$ either alone or in combination against hepatitis have been described previously $(18,19)$. Poor selenium intake can lead to enhanced levels of ROS and oxidative stress, particularly in patients lacking other antioxidants (e.g., vitamins E and C) (20). However, the role of selenium and the antioxidant combination (vitamins A, C, and E) has not been studied in terms of biochemical and histological impact.

The effects of a combination of antioxidants on histological and biochemical parameters in D-GalN-induced liver injury were studied here. Serum aspartate (AST) 
and alanine transaminase (ALT), alkaline phosphatase (ALP), gamma glutamyl transpeptidase (GGT), catalase (CAT), and lactate dehydrogenase (LDH) activities, as well as serum sialic acid, uric acid, blood glutathione, liver glutathione, lipid peroxidation (LPO) levels, catalase (CAT), superoxide dismutase (SOD), glutathione-S-transferase (GST), and GPx activities, as well as histopathology of liver tissue were analyzed to understand D-GalN toxicity.

\section{MATERIALS AND METHODS}

\section{Animals}

Forty female Sprague-Dawley rats (age, 2-2.5 months) were obtained from the Experimental Medical Research Institute of Istanbul University (DETAE). All rats were clinically healthy and approximately the same weight. The rats were fed a standard rat chow and given water ad libitum.

\section{Experimental Design}

The rats were separated into four groups of 10 rats each: 1) control animals (administered $0.9 \% \mathrm{NaCl}$ intraperitoneally); 2) control animals given antioxidants $(100 \mathrm{mg} / \mathrm{kg} /$ day ascorbic acid, $100 \mathrm{mg} / \mathrm{kg} /$ day alpha tocopherol, $15 \mathrm{mg} / \mathrm{kg} /$ day beta carotene, and $0.2 \mathrm{mg} / \mathrm{kg} /$ day sodium selenate); 3) animals given only a single dose of D-GalN hydrochloride $(500 \mathrm{mg} / \mathrm{kg}$, Acros Organics, Pittsburgh, PA, USA) (dissolved in 0.9\% NaCl); and 4) animals given D-GaIN + antioxidants (same doses and time). D-GalN was administered on day 3, 1 hour after the antioxidant combination. The antioxidants were administered by gavage, and D-GaIN was given intraperitoneally. Control and D-GaIN animals were separated 6 hours after the injection. On day 3 of the experiment, all animals were fasted overnight, and rats were sacrificed 7 hours after the last antioxidant administration. Blood samples were collected and liver tissue samples were obtained for biochemical and histological analyses.

\section{Histological Assays}

Bouin's fixative was used to prepare the liver samples, which were embedded in paraffin. Masson's trichrome stain was used to stain tissue sections for histological observations using a light microscope (CX41; Olympus, Tokyo, Japan).

\section{Biochemical Assays}

Blood and liver samples were taken from the animals. Serum and liver tissue samples were frozen until use. The $18 \mathrm{~h}$-fasting blood and liver glutathione levels were assayed according to Beutler (1975) (21). AST, ALT (22), ALP (23), GGT (24), LDH (25), sialic acid, (26) and uric acid levels (27) were assayed in serum samples. Protein levels were estimated by the Lowry method (28).

Tissue samples were homogenized in cold $0.9 \% \mathrm{NaCl}$ to prepare the $10 \%(\mathrm{w} / \mathrm{v})$ homogenates. The homogenates were centrifuged, and the supernatants were removed. CAT (29), SOD (30), GST $(31)$, and GPx $(32,33)$ activities were assayed in appropriately diluted liver tissue homogenates. LPO levels in liver homogenates were assayed according to Ledwozyw et al. (34).

\section{Statistical Analysis}

The biochemical results were analyzed using NCSS statistical software (NCSS Inc.; Kaysville, UT, USA). All data are expressed as mean \pm standard deviation. A $p$-value $<0.05$ was considered significant.

\section{RESULTS}

\section{Light Microscopic Results}

Liver tissues from animals given saline or the antioxidants (groups 1 and 2, respectively) had normal histology except for vacuolization that was observed in liver cells from group 2 (data not shown). The D-GalN-injected rats (group 3) had significant histopathological changes in the liver (Figure 1). Increased hyperemia, moderate vacuolization, enlargement in the sinusoidal area, necrotic, and swollen cells with a light cytoplasm were observed in the D-GaIN group vs. control groups 1 and 2 . Administering selenium and the antioxidants reversed the histopathological changes in D-GalN-injected animals. A decrease in mononuclear cell infiltration and hyperemia was observed in group 4 animals. However, vacuolization was observed in group 2 animals. These results indicate that administering selenium and the antioxidants may suppress the histological changes, except vacuolization in the liver of D-GaIN- injected rats.

\section{Biochemical Results}

Changes in serum AST, ALT, ALP, and GGT in the control and experimental groups are shown in Table 1. Serum AST $(p<0.0001)$, ALT $(p<0.0001)$, ALP $(p<0.0001)$, and GGT $(p<0.0001)$ activities were significantly higher in the D-GalN group compared to those in the control group. Administering the antioxidants significantly decreased serum AST $(p<0.005)$, ALT $(p<0.05)$, ALP $(p<0.05)$, and GGT $(p<0.005)$ activities in the D-GalN group (Table 1).

Blood GSH levels and serum LDH and CAT activities for all groups are shown in Table 2. Blood GSH values were significantly lower in the experimental group compared to those in the control group $(p<0.0001)$, but CAT activity did not change. A significant increase in serum LDH activity was observed in the D-GalN group $(p<0.005)$ compared with control rats. Administering antioxidants significantly increased blood GSH levels $(p<0.0001)$ and CAT $(p<0.005)$ activity, but decreased LDH activity in the $D$-GalN group $(p<0.0001$, Table 2$)$.

Serum sialic acid and uric acid levels were significantly higher in the D-GalN group compared with those in the control group $(p<0.0001)$ (Table 3). Antioxidant administration caused a significant decrease in mean serum sialic acid $(p<0.0001)$ and uric acid $(p<0.005)$ values in the $D-G a l N$ group compared with those in the control group (Table 3).

Liver GSH $(p<0.005)$, CAT $(p<0.05)$, SOD $(p<0.05)$, and GPx $(p<0.05)$ activities decreased significantly in the $D$-GalN group, compared to those in the control group. Liver GST activity also tended to decrease but not significantly. Tissue LPO levels increased in the D-GalN group compared to those in the control group $(p<0.005)$. Administering the antioxi- 

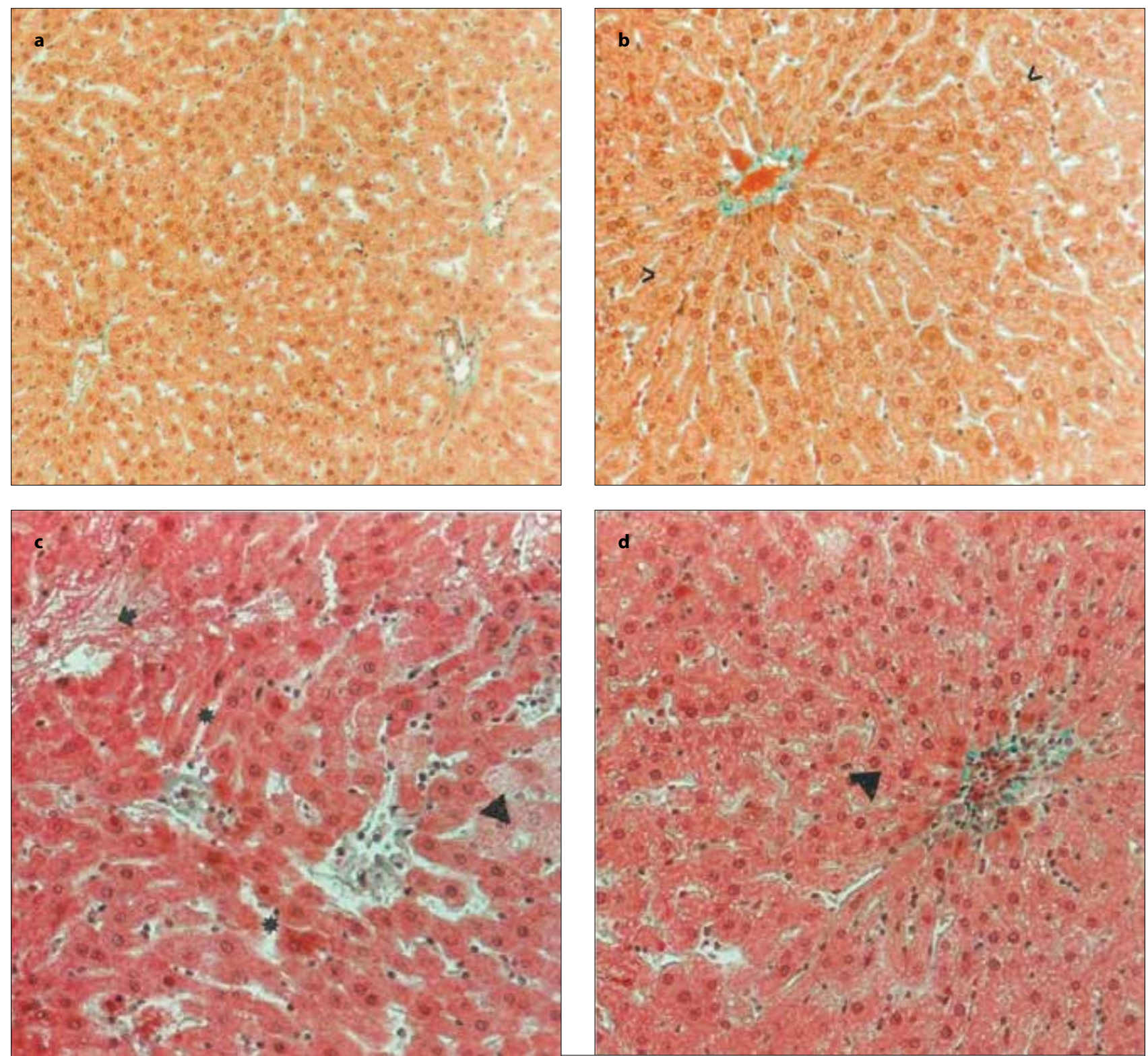

Figure 1. a-d. (a) Histological appearance of the liver of group 1 rats injected with physiological saline. (b) Histological appearance of the liver tissue of group 2 rats given selenium and the antioxidant combination. (c) Degenerative changes in the liver of the group 3 rats injected with D-galactosamine (D-GaIN). Enlarged sinusoidal spaces $(*)$, necrotic areas $(\rightarrow)$, and swollen cells with light cytoplasm ( $)$. (d) Histological appearance of the liver tissue of group 4 rats given selenium and the antioxidant combination and injected with D-GalN. Cellular vacuolization ( $)$. Masson's trichrome (270x).

dants significantly increased tissue GSH level $(\mathrm{p}<0.0001)$ and CAT $(p<0.05)$, SOD $(p<0.005$,$) and GPx (p<0.0001)$ activities in the D-GalN group. Liver GST activity did not change. Liver LPO level decreased significantly in the D-GalN+antioxidant group $(p<0.005)$ (Table 4$)$.

\section{DISCUSSION}

Acute liver failure significantly affects many bodily functions (35). Animal models of liver injury have been used to study acute liver failure, and D-GaIN administration is a good liver failure model (36). Other organs are affected by D-GalN admin- istration (37). D-GalN accelerates oxidative stress by increasing ROS production $(36,37)$. Administering D-GaIN consumes antioxidant compounds in the liver (38).

Administering $D$-GalN generated free radicals that stimulated LPO. D-GalN in combination with lipopolysaccharide treatment induces hepatotoxicity and significantly increase all markers of liver injury and LPO (39). Several researchers have suggested that various compounds, such as flavonoids, lycopene, and magniferin, ameliorate D-GalN-induced acute liver injury due to their antioxidant activities (40-42). Therefore, it can be in- 
Eur J Biol 2017; 76(1): 14-9

Catal et al. An Antioxidant Combination Improves D-Galactosamine-Induced Hepatotoxicity

\begin{tabular}{|c|c|c|c|c|}
\hline Group & AST (U/L)* & ALT (U/L)* & $\operatorname{ALP}(\mathrm{U} / \mathrm{L})^{*}$ & GGT (U/L)* \\
\hline Control & $51.63 \pm 6.77$ & $9.26 \pm 2.90$ & $29.78 \pm 7.75$ & $4.77 \pm 0.41$ \\
\hline Control + Antioxidant & $56.10 \pm 34.94$ & $57.89 \pm 8.58$ & $42.30 \pm 15.09$ & $2.41 \pm 1.11$ \\
\hline D-GalN & $97.46 \pm 12.08^{a}$ & $71.16 \pm 7.65^{a}$ & $65.88 \pm 5.83^{a}$ & $13.24 \pm 1.70^{a}$ \\
\hline D-GalN + Antioxidant & $67.88 \pm 20.99^{b}$ & $46.85 \pm 5.66^{c}$ & $48.28 \pm 12.84^{c}$ & $3.19 \pm 2.23^{b}$ \\
\hline$p_{\text {ANOVA }}$ & 0.0001 & 0.0001 & 0.0001 & 0.0001 \\
\hline $\begin{array}{l}{ }^{*} \text { Mean } \pm \text { standard deviation } \\
\text { a } p<0.0001 \text { compared with the control group } \\
\text { b } p<0.005 \text { compared with the D-GalN group } \\
{ }^{c} p<0.05 \text { compared with the D-GalN group }\end{array}$ & & & & \\
\hline
\end{tabular}

Table 2. Blood GSH levels and serum LDH and CAT activities for all groups

\begin{tabular}{lccc}
\hline Group & GSH (mg\%)* & LDH (U/L)* & CAT (U/L)* \\
\hline Control & $26.31 \pm 3.41$ & $1085.00 \pm 575.08$ & $22.92 \pm 2.27$ \\
\hline Control + Antioxidant & $20.68 \pm 3.91$ & $617.14 \pm 111.09$ & $28.85 \pm 12.45$ \\
\hline D-GalN & $17.18 \pm 3.14^{\mathrm{a}}$ & $2902.50 \pm 846.33^{\mathrm{c}}$ & $20.65 \pm 5.13$ \\
\hline D-GalN + Antioxidant & $24.82 \pm 2.82^{\mathrm{b}}$ & $810.00 \pm 434.24^{\mathrm{b}}$ & $38.89 \pm 6.17^{\mathrm{d}}$ \\
\hline$p_{\text {ANOva }}$ & 0.0001 & 0.0001 & 0.006 \\
\hline${ }^{*}$ Mean \pm standard deviation & & & \\
${ }^{\mathrm{a}} p<0.0001$ compared with the control group & & & \\
${ }^{\mathrm{b}} p<0.0001$ compared with the D-GalN group & & & \\
${ }^{c} p<0.005$ compared with the control group & & & \\
${ }^{\mathrm{d}} p<0.005$ compared with the D-GalN group & & & \\
\hline
\end{tabular}

Table 3. Serum sialic acid and uric acid levels for all groups

\begin{tabular}{lcc}
\hline Group & $\begin{array}{c}\text { Sialic acid } \\
(\mathbf{m m o l} / \mathbf{L}) *\end{array}$ & $\begin{array}{c}\text { Uric acid } \\
(\mathbf{m g} / \mathbf{d L}) *\end{array}$ \\
\hline Control & $0.81 \pm 0.31$ & $1.06 \pm 0.12$ \\
\hline Control+ Antioxidant & $0.59 \pm 0.15$ & $0.92 \pm 0.30$ \\
\hline D-GalN & $1.91 \pm 0.35^{\mathrm{a}}$ & $1.84 \pm 0.36^{\mathrm{a}}$ \\
\hline D-GalN + Antioxidant & $0.69 \pm 0.34^{\mathrm{b}}$ & $0.63 \pm 0.32^{\mathrm{c}}$ \\
\hline$p_{\text {ANOvA }}$ & 0.0001 & 0.0001 \\
\hline${ }^{*}$ Mean \pm standard deviation & \\
${ }^{\mathrm{a}} p<0.0001$ compared with the control group \\
${ }^{\mathrm{b}} p<0.0001$ compared with the D-GalN group \\
${ }^{c} p<0.005$ compared with the D-GalN group \\
\hline
\end{tabular}

ferred that selenium and antioxidant supplements can prevent D-GalN-induced hepatic damage.

Our results show that administering selenium and the antioxidants prevented histopathological liver damage in the D-GaIN group. Similarly, the use of antioxidant compounds, such as vitamin $\mathrm{E}$ ameliorated oxidative damage in tissues including the liver. Gezginci-Oktayoglu et al. (43) reported that a combination of selenium and vitamins $C$ and $E$ has a curative effect on hepatic damage. Ghrelin also improves the histopathological changes in the liver (44). Wild ginseng cambial meristematic cells protect the liver against GalN-induced inflammation, and sesamin ameliorates D-GalN/lipopolysaccharide-induced hepatic damage $(45,46)$. Forsythiaside has also been reported as a protective compound against lipopolysaccharide (LPS)/DGalN-induced liver injury (47). Genistein maintains the redox potential and improves the antioxidant defense system of cells to prevent hepatic and inflammatory diseases (48). Aristatile et al. (49) reported that carvacrol has hepatoprotective effects and alleviates liver injury caused by D-GalN-induced hepatotoxicity in rats. Li et al. (50) determined that linalool protects against liver damage induced by LPS/D-GalN through induction by antioxidants.

Various researchers have demonstrated enhanced antioxidant enzymatic activities in livers damaged by D-GaIN. Ai et al. (51) showed increased liver enzymatic activities, including SOD, GPx, and CAT caused by the phenolics obtained from Oenanthe javanica. Similarly, one study showed that rats injected with D-GaIN/LPS develop hepatic damage, and AST and ALT levels increase significantly (36). Blood urea nitrogen also changes in the liver of rats after treatment with D-GaIN/LPS (52). Ozden et al. (53) reported that vitamin $\mathrm{E}$ and taurine treatment significantly decreases tissue LPO levels.

Gezginci-Oktayoglu et al. (54) determined that oxidative stress decreases and antioxidant enzyme systems increase in response to administration of a Beta vulgaris L. var.cicla extract to injured rats based on decreased malondialdehyde formation (LPO), CAT activity, SOD, myeloperoxidase, and increased GSH levels in the liver. Similar biochemical results were reported in other organs, such as lungs injured by D-GaIN. The lung tissue damage occurred in D-GalN/tumor necrosis factor-alpha administered animals. Lung damage improves with the administration of Z-FA. FMK (55). Similarly, our results indicate that increased levels of serum AST, ALT, ALP, GGT, LDH, LPO, serum sialic acid, and uric acid were due to $D$-GalN administration, which decreased liver CAT, SOD, GST, and GPx activities as well as blood and liver GSH levels. Liver LPO levels increased in the D-GalN group. Treat- 


\begin{tabular}{|c|c|c|c|c|c|c|}
\hline Group & $\begin{array}{c}\text { GSH } \\
\text { (nmol GSH/ } \\
\text { mg prot.)* }\end{array}$ & $\begin{array}{c}\text { CAT } \\
\text { (U/mg prot.)* }\end{array}$ & $\begin{array}{c}\text { SOD } \\
\text { (U/g prot.)* }\end{array}$ & $\begin{array}{c}\text { GST } \\
\text { (U/mg prot.)* }\end{array}$ & $\begin{array}{c}\text { GPx } \\
\text { (U/mg prot.)* }\end{array}$ & $\begin{array}{c}\text { LPO } \\
\text { (nmol MDA/ } \\
\text { mg prot.)* }\end{array}$ \\
\hline Control & $54.61 \pm 17.10$ & $29.80 \pm 5.70$ & $17.45 \pm 7.62$ & $0.72 \pm 0.27$ & $1.76 \pm 0.59$ & $0.31 \pm 0.11$ \\
\hline Control + Antioxidant & $38.76 \pm 11.83$ & $69.05 \pm 11.86$ & $4.39 \pm 3.40$ & $0.64 \pm 0.14$ & $0.52 \pm 0.004$ & $0.36 \pm 0.09$ \\
\hline D-GalN & $32.41 \pm 5.06^{a}$ & $16.21 \pm 4.18^{c}$ & $4.79 \pm 0.15^{c}$ & $0.45 \pm 0.27$ & $0.80 \pm 0.48^{c}$ & $0.72 \pm 0.28^{a}$ \\
\hline D-GalN + Antioxidant & $65.08 \pm 8.16^{b}$ & $157.52 \pm 57.29^{d}$ & $25.15 \pm 5.06^{\mathrm{e}}$ & $0.60 \pm 0.22$ & $11.32 \pm 0.98^{\mathrm{b}}$ & $0.40 \pm 0.10^{e}$ \\
\hline$p_{\text {ANOVA }}$ & 0.0001 & 0.0001 & 0.0001 & 0.478 & 0.0001 & 0.0001 \\
\hline $\begin{array}{l}{ }^{*} \text { Mean } \pm \text { standard devia } \\
{ }^{\mathrm{a}} p<0.005 \text { compared wi } \\
{ }^{\mathrm{b}} p<0.0001 \text { compared } \\
{ }^{\mathrm{c}} p<0.05 \text { compared with } \\
{ }^{\mathrm{d}} p<0.05 \text { compared with } \\
{ }^{\mathrm{e}} p<0.005 \text { compared wi }\end{array}$ & $\begin{array}{l}\text { control group } \\
\text { D-GalN group } \\
\text { ontrol group } \\
\text {-GalN group } \\
\text {-GalN group }\end{array}$ & & & & & \\
\hline
\end{tabular}

ment with selenium and the antioxidant combination reversed these effects. We conclude that the antioxidant combination suppressed some histopathological changes and biochemical parameters in D-GaIN-hepatotoxicity of rats.

\section{Acknowledgements}

This study was supported by the Research Fund of Istanbul University (project no. T-290/18062003).

\section{REFERENCES}

1. Zhivkov V, Chelibonova-lorer H. The relative rate of synthesis of liver uridine diphosphate sugars in D-galactosamine-treated rats. Int J Biochem 1975: 6; 429-33. [CrossRef]

2. Catal T, Bolkent S. Combination of selenium and three naturally occurring antioxidants administration protects D-galactosamine-induced liver injury in rats. Biol Trace Elem Res 2008; 122(2): 127-36. [CrossRef]

3. Choi JH, Kang JW, Kim DW, Sung YK, Lee SM. Protective effects of Mg-CUD against D-galactosamine-induced hepatotoxicity in rats. Eur J Pharmacol 2011; 657(1-3): 138-43. [CrossRef]

4. Al-Chalabi A, Matevossian E, Thaden AK, Luppa P, Neiss A, Schuster T, et al. Evaluation of the Hepa Wash ${ }^{\oplus}$ treatment in pigs with acute liver failure. BMC Gastroenterol 2013; 13: 83. [CrossRef]

5. Yang $Q$, Liu Y, Shi Y, Zheng M, He J, Chen Z. The role of intracellular high-mobility group box 1 in the early activation of Kupffer cells and the development of Con A-induced acute liver failure. Immunobiology 2013; 218(10): 1284-92. [CrossRef]

6. Ytrebø LM, Rose CF. Significant advances towards a reproducible, clinically relevant large animal model of acetaminophen-induced acute liver failure. Liver Int 2013; 33(4): 499-500. [CrossRef]

7. Obayashi Y, Arisaka H, Yoshida S, Mori M, Takahashi M. Proline protects liver from D-galactosamine hepatitis by activating the IL-6/ STAT3 survival signaling pathway. Amino Acids 2012; 43(6): 237180. [CrossRef]

8. Wu MJ, Gong X, Jiang R, Zhang L, Li XH, Wan JY. Polydatin protects against lipopolysaccharide-induced fulminant hepatic failure in D-galactosamine-sensitized mice. Int J Immunopathol Pharmacol 2012; 25(4): 9233-34. [CrossRef]

9. Fink T, Heymann P, Taha-Melitz S, Taha A, Wolf $B$, Rensing $H$, et al. Dobutamine pretreatment improves survival, liver function, and hepatic microcirculation after polymicrobial sepsis in rat. Shock 2013; 40(2): 129-35. [CrossRef]
10. Kang JW, Kim DW, Choi JS, Kim YS, Lee S.M. Scoparone attenuates D-galactosamine/lipopolysaccharide-induced fulminant hepatic failure through inhibition of toll-like receptor 4 signaling in mice. Food Chem Toxicol 2013; 57: 132-9. [CrossRef]

11. Peng XR, Liu JQ, Han ZH, Yuan XX, Luo HR, Qiu MH. Protective effects of triterpenoids from Ganoderma resinaceum on H2O2-induced toxicity in HepG2 cells. Food Chem 2013; 141(2): 920-6. [CrossRef]

12. Lubos E, Loscalzo J, Handy DE. Glutathione peroxidase-1 in health and disease: from molecular mechanisms to therapeutic opportunities. Antioxid Redox Signal 2011; 15(7): 1957-97. [CrossRef]

13. Weeks BS, Hanna MS, Cooperstein D. Dietary selenium and selenoprotein function. Med Sci Monit 2012; 18(8): RA127-32. [CrossRef]

14. Du J, Cullen JJ, Buettner GR. Ascorbic acid: chemistry, biology and the treatment of cancer. Biochim Biophys Acta 2012; 1826(2): 44357. [CrossRef]

15. Zeng H, Cao JJ, Combs GF Jr. Selenium in bone health: roles in antioxidant protection and cell proliferation. Nutrients 2013; 5(1): 97110. [CrossRef]

16. Niki E, Traber MG. A history of vitamin E. Ann Nutr Metab 2012; 61(3): 207-12. [CrossRef]

17. von Lintig J. Provitamin A metabolism and functions in mammalian biology. Am J Clin Nutr 2012; 96(5): 1234-44. [CrossRef]

18. Bjelakovic G, Gluud LL, Nikolova D, Bjelakovic M, Nagorni A, Gluud C. Antioxidant supplements for liver diseases. Cohrane Database Syst Rev 2011; 16(3): CD007749. [CrossRef]

19. Kolachi NF, Kazi TG, Afridi HI, Kazi NG, Mughal MA, Khan S. Effects of selenium and zinc status in biological samples of hepatitis $C$ patient after herbal and pharmaceutical supplements. Biol Trace Elem Res 2013; 152(2): 187-94. [CrossRef]

20. Steinbrenner $\mathrm{H}$, Sies $\mathrm{H}$. Protection against reactive oxygen species by selenoproteins. Biochim Biophys Acta 2009; 1790(11):1478-85. [CrossRef]

21. Beutler E. Glutathione in red cell metabolism: a manuel of biochemical methods. 2nd ed, Grune and Stratton, New York, p. 112-4. (1975)

22. Reitman S, Frankel SA. Colorimetric method for the determination of serum glutamic oxalacetic and glutamic pyruvic transaminases. Am J Clin Pathol 1957; 28(1): 56-63. [CrossRef]

23. Walter $\mathrm{K}, \mathrm{Schütt} \mathrm{C}$. Acid and alkaline phosphatase in serum (two point method). Methods of Enzymatic Analysis. Vol. 2. Bergmeyer HU editor, Boca Raton, FL, USA: Verlag Chemie GmbH pp. 856-60. (1974)

24. Szasz G. A kinetic photometric method for serum $\gamma$-glutamyl transpeptidase. Clin Chem 1969; 15(2): 570-4. 
25. Wroblewski F. Clinical significance of serum enzyme alterations with myocardial infarction. Am Heart J 1957; 54(2): 219-24. [CrossRef]

26. Lorentz K, Weiss T, Kraas E. Sialic acid in human serum and cerebrospinal fluid. European J Clin Chem Clin Biochem 1986; 24(3): 189-98.

27. Caraway WT. Determinationof uric acid in serum by a carbonate method. Am J Clin Pathol 1955; 25(7): 840-5.

28. Lowry $\mathrm{OH}$, Rosebrough NJ, Farr AL, Randall RJ. Protein measurement with the folin phenol reagent. J Biol Chem 1951; 193(1): 26575.

29. Aebi H. Catalase in vitro. Methods Enzymol 1984; 105: 121-6. [CrossRef]

30. Mylroie AA, Collins H, Umbles C, Kyle J. Erythrocyte superoxide dismutase activity and other parameters of copper status in rats ingesting lead acetate. Toxicol Appl Pharmacol 1986; 82(3): 512-20. [CrossRef]

31. Habig W, Jacoby WB. Assays for differentiation of glutathione-S-transferases. Methods Enzymol 1981; 77: 398-405. [CrossRef]

32. Paglia DE, Valentine WN. Studies on the quantitative and qualitative characterization of erythrocyte glutathione peroxidase. J Lab Clin Med 1967; 70(1): 158-69.

33. Wendel A. Glutathione peroxidase. Methods Enzymol 1981; 77: 325-33. [CrossRef]

34. Ledwozyw A, Michalak J, Stepien A, Kadziolka A. The relationship between plasma triglycerides, cholesterol, total lipids and lipid peroxidation products during human atherosclerosis. Clin Chim Acta 1986; 155(3): 275-83. [CrossRef]

35. Tessier G, Villeneuve E, Villeneuve JP. Etiology and outcome of acute liver failure: experience from a liver transplantation centre in Montreal. Can J Gastroenterol 2002; 16(10): 672-6. [CrossRef]

36. Kemelo MK, Horinek A, Canová NK, Farghali H. Comparative effects of quercetin and SRT1720 against D-galactosamine/lipopolysaccharide-induced hepatotoxicity in rats: biochemical and molecular biological investigations. Eur Rev Med Pharmacol Sci 2016; 20(2): 363-71.

37. Saracyn M, Zdanowski R, Brytan M, Kade G, Nowak Z, Patera J, et al. D-Galactosamine intoxication in experimental animals: Is it only an experimental model of acute liver failure? Med Sci Monit 2015; 21: 1469-77. [CrossRef]

38. Choi JW, Kim IH, Kim YM, Lee MK Nam TJ. Pyropia yezoensis glycoprotein regulates antioxidant status and prevents hepatotoxicity in a rat model of D-galactosamine/lipopolysaccharide-induced acute liver failure. Mol Med Rep 2016; 13(4): 3110-4. [CrossRef]

39. Kemelo MK, Wojnarová L, Kutinová Canová N, Farghali H. D-galactosamine/lipopolysaccharide-induced hepatotoxicity downregulates sirtuin 1 in rat liver: role of sirtuin 1 modulation in hepatoprotection. Phsyiol Res 2014; 63(5): 615-23.

40. Das J, Ghosh J, Roy A, Sil PC. Mangiferin exerts hepatoprotective activity against $\mathrm{D}$-galactosamine induced acute toxicity and oxidative/nitrosative stress via Nrf2-NFkB pathways. Toxicol Appl Pharmacol 2012; 260(1): 35-47. [CrossRef]

41. Sheriff SA, Devaki T. Lycopene stabilizes lipoprotein levels during D-galactosamine/lipopolysaccharide induced hepatitis in experimental rats. Asian Pac J Trop Biomed 2012; 2(12): 97580. [CrossRef]
42. Dong M, Hong T, Liu S, Zhao J, Meng Y, Mu J. Hepatoprotective effect of the flavonoid fraction isolated from the flower of Inula britannica against D-galactosamine-induced hepatic injury. Mol Med Rep 2013; 7(6): 1919-23. [CrossRef]

43. Gezginci-Oktayoglu S, Basaraner $\mathrm{H}$, Yanardag R, Bolkent $\mathrm{S}$. The effects of combined treatment of antioxidants on the liver injury in STZ diabetic rats. Dig Dis Sci 2009; 54(3): 538-46. [CrossRef]

44. Koyuturk M, Sacan O, Karabulut S, Turk N, Bolkent S, Yanardag R, et al. The role of ghrelin on apoptosis, cell proliferation and oxidant-antioxidant system in the liver of neonatal diabetic rats. Cell Biol Int 2015; 39(7): 838-41. [CrossRef]

45. Kim SJ, Choi HS, Cho HI, Jin YW, Lee EK, Ahn JY, et al. Protective effect of wild ginseng cambial meristematic cells on D-galactosamine-induced hepatotoxicity in rats. J Ginseng Res 2015; 39(4): 376-83. [CrossRef]

46. Ma L, Gong X, Kuang G, Jiang R, Chen R, Wan J. Sesamin ameliorates lipopolysaccharide/d-galactosamine-induced fulminant hepatic failure by suppression of Toll-like receptor 4 signaling in mice. Biochem Biophys Res Commun 2015; 461(2): 230-6. [CrossRef]

47. Pan CW, Zhou GY, Chen WL, Zhuge L, Jin LX, Zheng Y, et al. Protective effect of forsythiaside $A$ on lipopolysaccharide/d-galactosamine-induced liver injury. Int Immunopharmacol 2015; 26(1): 80-5. [CrossRef]

48. Ganai AA, Khan AA, Malik ZA, Farooqi H. Genistein modulates the expression of NF-KB and MAPK ( $p-38$ and ERK1/2), thereby attenuating $D$-galactosamine induced fulminant hepatic failure in Wistar rats. Toxicol Appl Pharmacol 2015; 283(2): 139-46. [CrossRef]

49. Aristatile B, Al-Assaf AH, Pugalendi KV. Carvacrol ameliorates the PPAR-A and cytochrome P450 expression on D-galactosamine induced hepatotoxicity rats. Afr J Tradit Complement Altern Med 2014; 11(3): 118-23. [CrossRef]

50. Li J, Zhang $X$, Huang $H$. Protective effect of linalool against lipopolysaccharide/D-galactosamine-induced liver injury in mice. Int Immunopharmacol 2014; 23(2): 523-9. [CrossRef]

51. Ai G, Huang ZM, Liu QC, Han YQ, Chen X. The protective effect of total phenolics from Oenanthe javanica on acute liver failure induced by D-galactosamine. J Ethnopharmacol 2016; 186: 53-60. [CrossRef]

52. Wang JB, Wang HT, Li LP, Yan YC, Wang W, Liu JY, et al. Development of a rat model of D-galactosamine/lipopolysaccharide induced hepatorenal syndrome. World J Gastroenterol 2015; 21(34): 992735. [CrossRef]

53. Ozden S, Catalgol B, Gezginci-Oktayoglu S, Karatug A, Bolkent S, Alpertunga $B$. Acute effects of methiocarb on oxidative damage and the protective effects of vitamin $E$ and taurine in the liver and kidney of Wistar rats. Toxicol Ind Health 2013; 29(1): 60-71. [CrossRef]

54. Gezginci-Oktayoglu S, Sacan O, Bolkent S, Ipci Y, Kabasakal L, Sener G, Yanardag R. Chard (Beta vulgaris L. var. cicla) extract ameliorates hyperglycemia by increasing GLUT2 through Akt2 and antioxidant defense in the liver of rats. Acta Histochem 2014; 116(1): 32-9. [CrossRef]

55. Oztay F, Gezginci-Oktayoglu S, Bayrak BB, Yanardag R, Bolkent S. Cathepsin $B$ inhibition improves lung injury associated to $D$-galactosamine/tumor necrosis factor-alpha-induced liver injury in mice. Mol Cell Biochem 2010; 333(1-2): 65-72. [CrossRef] 